\title{
Continuous isomerization of glucose to fructose using activated hydrotalcite catalyst: Effects of reaction conditions
}

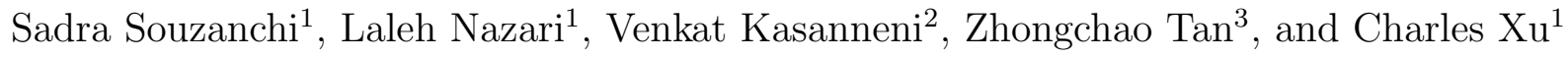 \\ ${ }^{1}$ Western University \\ ${ }^{2}$ University of Western Ontario \\ ${ }^{3}$ University of Waterloo
}

December 22, 2021

\begin{abstract}
Isomerization of glucose to fructose was studied over activated hydrotalcite as a catalyst in a continuous-flow tubular reactor. The synthetic hydrotalcite (HT), calcined hydrotalcite (HT-C) and activated hydrotalcite (calcined-rehydrated hydrotalcite (HT-C-R)) were characterized by TGA, XRD, BET surface area, and FT-IR analyses. The effects of operating conditions, including reaction temperature and retention time (in terms of both catalyst loading and feeding flow rate) on the isomerization reaction, were investigated. Glucose conversion and fructose selectivity were found to be more strongly dependent on retention time than reaction temperature. The fructose yield was mostly dependent on the feeding flow rate, and its maximum value of $18 \%$ corresponded to the lowest flow rate of $0.5 \mathrm{ml} / \mathrm{min}$. The regenerated hydrotalcite catalyst showed that the catalyst activity could be restored through the calcination-rehydration process, and it showed good potential for recycling and reusability.
\end{abstract}

\section{Hosted file}

Manuscript.docx available at https://authorea.com/users/452218/articles/550336-continuousisomerization-of-glucose-to-fructose-using-activated-hydrotalcite-catalyst-effects-ofreaction-conditions 